\title{
SPEECH EXPERIENCE AND SOCIAL INTELLIGENCE OF THE PRIMARY SCHOOL AGE CHILDREN
}

\section{Orap M. O.}

\section{INTRODUCTION}

Socio-psychological development of the personality involves the formation of abilities and properties that ensure its social adequacy and compliance with the requirements of society. The characteristics of flexibility and adaptability in social relations, adequacy of prediction the results of social interaction are emerging in modern social life. That is why the problems of social intelligence are intensified in scientific psychological researches. Social intelligence is considered by scientists as a system of psychological mechanisms that make it possible to build a subjective picture of the world and to make social interaction. Such general definition emphasizes the significance of this phenomenon in psychological and social life of the personality.

The problem of social intelligence ontogenesis is one of the fundamental questions of the nature of intelligence at all. Ontogenesis studies allow us to answer the question of the innate or acquired, nature or social character of social intelligence, the factors that influence it and the basic regularities of its functioning. Scientific researchers in this direction sends us to the classical works by H.Eysenck, J. Guilford about the innate character of human intelligence ${ }^{1 ; 2}$. All significant studies of social intelligence necessarily address the issues of its genesis, since the regularities of its functioning at all are most adequately and fully disclosed through the process of formation of social intelligence in ontogenesis.

In this aspect, two main research questions are clearly distinguished: 1) the correlation of biological and social factors in formation and functioning of social intelligence, the role of innate mechanisms in the development of social skills (M.I. Bobneva,

${ }^{1}$ Айзенк Г. Ю. Понятие и определение интеллекта. Вопросы психологии. 1995. № 1. C. 111-131.

${ }^{2}$ Guilford J. P. The nature of human intelligence. N.Y.: McGraw-Hill, 1967. 156 p. 
J. Guilford, A.I. Savenkov); 2) the main regularities and age features of the formation the components of social intelligence in ontogenesis, the age patterns and peculiarities of its development (N.F. Kalina, T.N. Karpovich, L.O. Lyakhovets, Yu.M. Fadeeva), definition of pedagogical and methodological conditions for its optimal development (Ya.O. Kaplunenko, A.A. Melnik, O.V. Sheshukova).

The general principle of social intelligence ontogenetic researches is to compare indicators of general and social intelligence (R. Riggio, D. Keating, D. Coleman). Therefore, the diagnostic of social intelligence mostly repeats traditional tests of intelligence, but is characterized by a greater cognitive-verbal orientation. This raises the question about the role of verbal and non-verbal components in the functioning of social intelligence. Studies have revealed the independence the verbal part of general intelligence and social intelligence (J. Wedeck). That is, the high level of verbal intelligence does not always cause and does not always affect the high level of social intelligence. However, studies of psycholinguists (J.W. Pennebaker, D. Slobin, L.S. Vygotsky, A.A. Leontiev) show that success in communication depends significantly on the level of personality's speech activity development, on her speech skills and abilities, and speech competence. Thus, the question of the role of verbal components (in particular, speech experience) in the formation and functioning of social intelligence remains beyond the attention of psychological researchers. This causes us to study the mutual influence of speech experience and social intelligence of the primary school age children.

\section{Speech experience of the primary school age children}

Theoretical analysis of the speech development problems demonstrates the lack of joint and common approach to the problem. Despite considerable research attention to the problem of speech development as the A.A. Leontiev says, "... there is still no developed theory of controlled and conscious speech, although the creation of such theory would have great importance for the improvement of teaching reading and writing, native and foreign language ${ }^{\prime 3}$. Thus, the theory and

3 Леонтьев А. А. Основы психолингвистики: научн. пособие. 3-е изд. М. : Смысл; СПб : Лань, 2003. 287 с. 
practice of education have needed to study the psychological patterns of children's speech development from new methodological positions. In our opinion, the solution of this problem is possible using the research of speech experience: studying the structure, identification of functional features and dynamics of the structural elements of the speech experience.

The main task and problem of the modern researchers of speech, in our opinion, is to determine - what exactly is the speech development of children of primary school age. Is it the accumulation and organization of language units, or is it improving of speech activity, or is it taking the speech competency? Analysis of theoretical literature and practice of the children speech development leads us to believe that all the above phenomena that describe the complex mechanism of human speech, are the units of a higher order. Thus, we come to the idea of speech experience, which we see as individual speech system, which enables the speech mastering of the world. Speech experience is a system in the psyche of the individual, which is the process of processing and ordering the results of speech mastering of the world. Personality's language view of the world, speech competency and speech culture are the products of such mastering. Analysis of speech development from the standpoint of child's speech experience allows describing its structure as a system of interconnected functional elements. This allows splitting the process of speech development for constituents that determine its dynamic and analyze each of them separately.

Our theoretical model of personality's speech experience, built on the basis of the structural-functional approach, allows us to clearly identify the parameters of its structure ${ }^{4}$ The speech experience is considered as a system, which is a set of elements that are in relationships and interconnections between themselves and form a certain integrity, which ensures the personality's speech mastering of the world. Proceeding from the structural - functional principle and two complementary functions that ensure the integral functioning of the system, we have identified and empirically studied the structure of the speech experience, which we consider as a synthesis of internal and external structures. The function of the internal structure is the

4 Орап М. О. Психологія мовленнєвого досвіду особистості: монографія. Тернопіль: «Підручники і посібники», 2014. 480 с. 
consolidation, organization and systematization the results of speech mastering of the world by means of speech ability, speech capabilities, speech competence and speech activity. The external structure is aimed at mediating the speech mastering of the world on the basis of the verbal picture of the world, speech competency and speech culture (Orap, 2014).

Physiological precondition of the speech experience is speech ability. Speech capabilities cause the individual expression of personality's speech ability and formation of speech competence and activity. Learning of language skills and knowledge of the language creates personality's individual set of language and speech knowledge that combined in speech competence. This language means and manner of speech are forming and formulated thought that is the central link of the speech activity. Thus, the structure of the child's speech experience presented by the speech ability, speech capabilities, speech competence and speech activity. In this aspect speech ability determines the potential possibility of speech activity; speech capabilities determine the individuality in mastering the knowledge of speech (speech competence) and formation of speech skills (speech activity).

In order to verify the theoretical model, we performed an empirical study of interrelations between these elements of speech experience. Diagnostic testing of the internal structure of speech experience was covered 291 child of primary school age. Speech experience studied as an experience of mastering the world using their native language. So the sample group have been formed of children whose native language of everyday communication is Ukrainian.

The results of our comprehensive empirical study were quantitatively and qualitatively processed. Each element of the internal structure of the speech experience - speech ability, speech capabilities, speech competence and speech activity - were diagnosed by allocated indicators. We expect that the qualitative and quantitative peculiarities of structural elements are conditioned by structural and functional features of the interrelations between their constituents. Certain level of regulation of structural and functional interrelations between components of structural elements understood as "level of system organization".

The level of ordering components of the internal structure of the speech experience determines the success of diagnostic techniques, and generally high rates of diagnosis. Thus, the results of empirical research 
would be described more exactly by definition "level of organization" and not "level of development" (as the patterns of speech experience genesis and its development has not investigated). Therefore, each structural element is described by a certain level of organization - the higher the level of interaction between components - the higher level of the organization means the higher efficiency of personality's speech mastering of the world. Provides that a high degree of structural differentiation and integration (that means - organization) ensure the effective functioning the elements of speech experience.

I. Speech ability. We studied speech ability through the diagnostic indicators and contained six techniques that were diagnosed: 1) language and speech disorders, 2) understanding relationships between words, 3) understanding of verbal material, 4) logical characteristics of associative reactions, 5) perception and understanding of speech, 6) willingness to produce speech. Determining the level of each indicator speech given ability to determine the general level of speech ability as an overall results indicator. So, a high level of speech ability was diagnosed in $24,74 \%$ of respondents, average $-53,61 \%$, the lowest in $21,65 \%$ of respondents. Determining the overall level of speech ability made it possible to compare the value of each empirical referent in the structure of the speech ability. The results of all diagnostic techniques show positive correlation with general level of speech ability, lack of speech disorders $(\mathrm{r}=0,567)$, understanding relationships between words $(\mathrm{r}=0,534)$, understanding verbal material $(\mathrm{r}=0,576)$, characteristics associative responses $(\mathrm{r}=0,517)$, perception and understanding of the expression $(\mathrm{r}=0,506)$, ready to produce expression $(\mathrm{r}=0,440)$. There is a situation where all diagnostic indicators of speech ability show almost the same indicators of statistically significant positive correlation with the general level of speech ability. This suggests that all emphasized elements of speech ability have equally influence to formation the capacity for speech.

II. Speech competence. Empirical referents of speech competence were defined: 1) the level of operational knowledge; 2) understanding language patterns (implicit knowledge); 3) perception and understanding of speech patterns; 4) the level of language proficiency and 5) correct vocabulary (declarative explicit knowledge); 6) knowledge of rules of the use of language units and 7) arbitrary speech (procedural knowledge). The general level of speech competence was determined by 
levels: medium group rate $(\mathrm{M})=13,021$, high levels defined within: 16-20 points; the average $-11-15$ points, low $-10-6$ points. This allowed determining the level of speech competence. Analysis of levels of speech competence showed that the highest percentage of respondents characterized by average $-58,76 \%, 18,56 \%$ have found a high level and $20,62 \%$ - a low level of speech competence. All empirical referents have statistically significant correlation coefficients with the general level of speech competence, level of speech-and-thinking operations $(r=0,556)$, understanding speech patterns $(\mathrm{r}=0,499)$, perception and understanding of speech patterns $(r=0,499)$, the level of language skills $(r=0,653)$, vocabulary accuracy $(\mathrm{r}=0,546)$, knowledge of the rules of use of speech units $(r=0,603)$, the arbitrariness of speech $(r=0,518)$. As the qualitative analysis of correlations between some indicators of speech competence, the most essential to its functioning are: the level of language skills and their accuracy and knowledge of the rules of use of language units and therefore knowledge of the rules of speech material operations. Thus, speech competence children of primary school age functions as interrelated structure of operational, implicit and explicit knowledge.

III. Speech capabilities. Speech capabilities were studied through diagnosis: 1) the level of verbal thinking, 2) originality of the images, 3) semantic flexibility 4) plasticity of speech, 5) verbal creativity 6) divergent productivity on verbal material, 7) initiative in speech activity. Transfer the diagnostic techniques results in points gives us the general level of speech capabilities: medium group rate $M=10,360$; high level: 13-18 points; the average, 9-12 points; low: 3-8 points. Analysis of the general level of skills of speech shows that the largest percentage of respondents characterized by average $-52,58 \%$ level. High levels observed in $22,68 \%$ and the lowest - in $24,74 \%$ of the respondents. Statistically significant correlations was founded between indicators of the general level of speech capabilities and semantic flexibility $(\mathrm{r}=0,529)$, verbal creativity $(\mathrm{r}=0,450)$, divergent productivity $(\mathrm{r}=0,501)$ and plasticity of speech $(\mathrm{r}=0,517)$. Thus, the prerequisites for the development of speech capabilities are the ability of a child to words free operating according to more adequately reflect the intellectual content and the ability to solve intellectual-speech problem in different ways, with different language means selection. The least 
influence to the general level of speech capabilities was showed by initiative in speech activity $(\mathrm{r}=0,326)$.

IV. Speech activity. The level of speech activity was studied by diagnosis: 1) the number of motives communication, 2) analysis of the precision of speech skills, 3) the rate of writing, 4) the level of speech facilities, 5) the level of allocation of essential features of meanings, 6) level of integration of meanings (characteristic grammatical associative reactions), 7) the level of understanding of metaphorical words, 8) features a frame, 9) features the script. The general level of speech activity is determined by means of conversion the marks into balls and levels: medium group rate $(\mathrm{M})=17,113$, high: $20-26$ points; the average: $15-19$ points; low: 8-14 points. Accordingly, revealed that $24.74 \%$ of children characterized by a high level of speech activity, $53,61 \%$ - average and 21,65 - a low level of speech activity. Qualitative analysis the results of correlation analysis revealed the most significant components for the functioning of speech experience. We analyzed the correlation between the indicators of the level of speech activity and its empirical referents. Its shows that the leading role in functioning of the speech activity belongs to the operational components - level of accuracy $(\mathrm{r}=0,583)$ and fastness $(\mathrm{r}=0,522)$ of speech skills. In addition, confirmed the conclusion by L.S.Vygotsky that speech development is the process of generalization the meanings. Important role in the functioning of speech activity have exactly operations with meanings - the allocation of essential features $(r=0,542)$ and ordering a representative structures of the script $(r=0,509)$ and frame $(r=0,469)$.

The analysis of correlations between the levels of organization the elements of the internal structure of the speech experience of children of primary school age demonstrates the presence of statistically significant (for accepted significance level $\mathrm{p}<0,001$ ) correlations between all defined elements. This means that between all elements of the structure are interconnections and interdependence: one element changes cause changes in other elements. That gives grounds to assert that the internal structure of speech experience is functioning on the systematic principles.

Qualitative analysis of correlations between the levels of the elements of the internal structure demonstrates its homogeneity and uniformity. For existing statistically significant relationships between all elements, differences in coefficient of correlation is not statistically 
significant, which does not allow us to speak about the dominance and leadership role of some specific connections.

This allows us to predict that the internal structure of the speech experience of children of primary school age functions as undifferentiated and close cooperation between all the elements themselves, without a clear separation of some structural elements. Differences in the correlation coefficient between the indicators of the internal structure of speech experiences of children of primary school age are insignificant. Thus, the structure is not yet quite clear and not hierarchically ordered. In other words, the speech experience is not yet active means of mastering of the world, but is a means of studying the world. In this aspect prevails function of thoughts forming and formulating, intellectual function of speech experience. Comparison the significance of correlation shows the homogeneity of the structure. However, was detected a slight, but the prevalence of the importance of correlations between the speech ability and speech competence $(\mathrm{r}=0,518)$ and between speech capabilities and speech activity $(r=0,505)$, suggesting a trend to a hierarchy in which speech ability and speech capabilities are lower fundamental level of the speech experience internal structure.

\section{Social intelligence of the primary school age children}

The analysis of social intelligence researches has shown that one of the main questions is the question of interconnection and interaction between general (academic, abstract, practical) and social intelligence. As E.Z. Ivashkevich notes, in addition to the question of the content of social intelligence, the problem of correlation between social and general intellect, intellectual abilities and capabilities, communicative activity etc, remains unresolved ${ }^{5}$. In this question, based on the scientific literature analysis, we have identified three main approaches. First, social intelligence is seen as a kind of general intelligence $(\mathrm{H}$. Eysenck, H. Gardner, R. Sternberg, D. Wechsler). The general common idea of these researches is about social intelligence as a part of general that show up in the situations of social interaction or in the social life at all.

${ }^{5}$ Івашкевич Е. 3. Соціальний інтелект педагога : монографія. К.: Принт-Хауз, 2017. $532 \mathrm{c}$. 
The second direction studying social intelligence as separate form of intelligence that aims at personality's adaptation in society and solving life problems. According to E. Thorndike, J. Guilford, M.I. Bobneva and other, social intelligence is not a part of general intelligence and is not related to it. Researches by J. Guilford and M. Sallivan, M. Ford, L. Braun, R.L. Selman have shown that the level of social intelligence differs from the academic one, but there is a potential interconnection between them. Further in the studies of J. Wedeck (1947), it was proved that the social intelligence does not significantly correlate with the development of general intelligence and space representations. It should be emphasized that in the studies of J.Guilford social intelligence did not significantly correlate with the development of general intelligence, the ability to visualize and the originality of thinking.

In the third approach social intelligence is represented as based on personal characteristics and levels of self-awareness integral ability to communicate (N. Cantor, J. Kihlstrom, V.M. Kunitsina). The emphasis is on the communicative orientation of social intelligence and is therefore aimed at measuring personal characteristics that correlate with the parameters of social competence ${ }^{6}$. Such researches are very close to the problems of social interaction, communication and some kinds of knowledge, skills and abilities that enable its functioning.

If we turn to the definition of intelligence as "the cognitive ability to all levels of reflection, prediction and rational transformation of reality, as penetrating all spheres of personal life of a person and the activities of the subject of knowledge" ${ }^{7}$, the most appropriate is the consideration of social intelligence as a cognitive ability to reflect, predict and appropriate transformation of circumstances, subjects and content of social interaction. Thus, we define social intelligence as an ability that arises on the basis of a complex of intellectual, personal, communicative and behavioral features that predict the development of interpersonal situations, the interpretation of information and behavior, readiness for social interaction and decision-making. All phenomena analyzed above (social knowledge, skills, abilities,

${ }^{6}$ Cantor N. Personality and social intelligence/ N. Cantor, J.F. Kihlstrom. - NJ Prentice-Hall,1987. 200 p.

Засєкіна Л. В. Структурно-функціональна організація інтелекту : монографія . Острог : Вид-во Нац. ун-ту «Острозька академія», 2005. 370 с. 
competence, ability, etc.) in this case, are considered as a predictors of successful functioning of the social intelligence. That is why we accept and share the opinion of A.A. Melnyk that research of ontogenesis of social intelligence should be conducted using the psychometric direction, within the definition of criteria and indicators of development of social intelligence ${ }^{8}$.

This determines the necessity of creating the integrated program of empirical research of social intelligence of the primary school age children. The solution of this task required, first, the definition of empirical referents (diagnostic indicators) of the structure of social intelligence, taking into account age characteristics in accordance with the proposed theoretical model, and secondly, the selection, creation and theoretical justification of a set of diagnostic techniques that allow us to examine the structural- functional features of social intelligence. The theoretical model of organization social intelligence, built on the principles of structural-functional approach, allows us to clearly identify the structural elements: 1) emotional intelligence, 2) socialperceptive anticipation, 3 ) the success of social interaction.

1. Emotional intelligence is considered by psychologists in the general sense as the ability to recognize their own emotions and feelings, as well as emotions and feelings of other people; and apply this information to manage their own thoughts and actions. Nowadays in Ukraine studying the problem of general conceptualization this phenomenon, selection its functions (E.L. Nosenko), emotional intelligence as a main determinant of internal freedom of the individual (G.I. Berezyuk) and the indicator of its holistic development (O.V. Filatova). Psychologists have proved the possibility and prerequisites for a specially organized formation of emotional intelligence (I.M. Andreyev, T.A. Berezovsky, O.A. Miloslavskaya, A.M. Pankratova,). In study by O.V. Grib was found positive correlations of social and emotional intelligence with the greatest load on the indicator "empathy"9. This is confirmed that emotional intelligence is the main construct of social intelligence. From this point

${ }^{8}$ Мельник А. А. Особливості прояву складових соціального інтелекту дітей шкільного віке. Вісник Харківського національного університету ім. В.Н. Каразіна. Серія Психологія. 2011. № 959. Вип. 46. С. 109-113.

${ }^{9}$ Гриб Е.В. К вопросу о соотношении социального и других видов интеллекта. Историческая и социально-образовательная мысль. Том 9. № 1/1, 2017. С. 58-71. 
of view it is logical to agree with the opinion of D.V .Lyusin, who divides the emotional intelligence into interpersonal (that is, social) and intrapersonal (that is, emotional) ${ }^{10}$. Therefore, that part of the emotional intelligence, which is aimed at understanding and so-feeling of other people's emotions (that is, empathy) plays a leading role in the development of social intelligence ${ }^{11}$.

In modern psychological literature concept "empathy" meets a wide range of definitions through "empathy interaction", "empathy reaction", "empathy abilities" and synonyms ("altruism", "prosocial behavior", "social sensitivity"). Empathy, like any emotional phenomenon undergoes development. There are two consecutive evolving forms of empathy in ontogenesis - empathy as 1) compassion (conscious response to a real life situation) and 2) situational impulsive way of reacting to distress of another people. The younger school age is characterized as a qualitatively new stage in the child's life, which radically changes social status and system of social relations in a whole. This leads to forming new means and methods of child's social interaction, rebuilding the whole system of social contacts. The beginning of systematic education changes the system of social experience in direction of its normalization, alignment with the rules and intensive enrichment of the content. Thus, empathy at the junior school age determines the level of adequacy of understanding of others and their own emotions, which at this age forms the basis for forming of emotional intelligence ${ }^{12}$. Therefore, we allow that the indicator of emotional intelligence at the junior school age is the level of development of empathy can be diagnosed by the "Method of express diagnosis of empathy I.M. Yusupov".

2. Social-perceptual anticipation. As a result of analysis the content of "social intelligence" given by different authors we came to the conclusion that the specific characteristic that describes the reality of social intelligence itself (not social competence, social adaptability,

10 Люсин Д.В., Ушаков Д.В., Социальный интеллект: теория, измерение, исследования: монография. М.Изд-во «Институт психологии РАН», 2004. 176 с.

11 Журавльова Л.П. Психологія емпатії: монографія. Житомир: Вид-во ЖДУ ім. I Франка, 2007. 327 c.

${ }^{12}$ Ковалевская А.В. Опыт психологического исследования феномена эмпатии у младших школьников 9-11 лет. Психология. 2005. № 2. С. 31-37. 
social interaction skills, etc.) is precisely precognition - prediction of deploying a script and effects of social events. G. Allport said that the main component and condition for successful functioning of social intelligence is the ability to anticipate the effects of social interaction. In J. Guilford's test the idea of forecasting the possible effects of interaction is one of the main criterion of social intelligence. Nowadays approaches to the problem of anticipation are analyzed in detail by O.V. Romanenko (Romanenko, 2015), based on which we define the social-perceptual anticipation (by the level of mental reflection) by generic notions regarding prediction. In the research by I.G. Batrachenko emphasizes that anticipation as a specific ability is a complete formation, which has in its composition some subsystems. The main role in social and ontogenetic development of human anticipation belongs to cultural factors, which influence is reversed by individual peculiarities and social functions of a person. Individual human ability to anticipate is closely related to societal and social anticipation ${ }^{13}$. The author has shown that the process of anticipation moves from cognitive reflection, through emotional and volitional attitude, to the formation before the installation, which pass into the action.

In school child makes a new step in the development of perception, prediction and planning. School education arranges children by social orientations in space and time (P.P. Blonsky, L.O. Regush, O.Ya. Ponomariov), that is the preconditions for the development of socio-psychological anticipation. In primary school age social-perceptual anticipation develops in the direction of improving the child's ability to understand the logic of deployment of events and, at the same time, to improve the ability to prediction the effects of social interaction, which are determined the indicators of its development. The most adequate test for the diagnosis of these indicators of development the social-perceptual anticipation at the primary school age we suggest the sub-test "History with Completion" of the social intelligence test by J. Guilford (diagnostics of understandin the logic of deployment of events) and subchasses "Accusation" of the S. Rosenzweig method of studying the frustrating

${ }^{13}$ Батраченко І. Г. Психологія розвитку антиципації людини : монографія. Д. : Вид-во ДНУ ім. О. Гончара, 1996. 204 с. 
reactions. J. Guilford's test built on the basis of illustrations, comics and measures the factor of knowledge the results of behavior, that is, the ability to predict the consequences of the behavior in a particular situation, prediction of the logic of the deployment of events and the completion of the situation.

3. Social interaction. Communication with other children plays an important role at the primary school age. Skills of social interaction with a group of peers and the ability to make friends are one of the most important tasks for the child's development at this age. It makes self-esteem more adequate and helps to socialize children in the new environment ${ }^{14}$. In the primary school age friendship is becoming socio-psychological phenomenon with individual-deep interpersonal relationships of children ${ }^{15}$. Communication becomes a special school of social relations. Exactly in self-contained communication children discovered and opened a various styles of possible building relationships ${ }^{16}$. The study of peculiarities the social interaction among children of primary school age gives grounds to assert that the level of development of speech experience significantly influences the level and activity of social interaction in this age period. In many causes successful social relations at this age depend from child's speech competence - how correctly compose sentences, how clearly he/she can formulated thoughts and choose the right words. So we consider it necessary to include in the diagnostic program the indicator of determining the adequacy of the statement in situations of social interaction. That's why we decided to diagnostic the level of social interaction through evaluation the level of adequate of verbal reactions in different social situations by our author methods ${ }^{17}$. Collectively the programme of empirical studies children's social intelligence is presented at the Table 1 above.

14 Ляховець Л.О. Вікові особливості становлення соціального інтелекту. Вісник Чернігівського національного педагогічного університету. 2015. № 126. C. 102-106.

15 Мельник А. А. Особливості прояву складових соціального інтелекту дітей шкільного вік. Вісник Харківського національного університету ім. В.Н. Каразіна. Серія Психологія. 2011. № 959. Вип. 46. С. 109-113.

16 Драган А. О. Розвиток міжособистісних відносин дітей молодшого шкільного віку. Науковий вісник Миколаӥвського національного університету імені B. О. Сухомлинського. Серія : Педагогічні науки. 2015. № 1. С. 117-121.

17 Орап М. О. Психологія мовленнєвого досвіду особистості: монографія. Тернопіль: «Підручники і посібники», 2014. 480 с. 
Table 1

The programme of empirical studies social intelligence of the primary school age children

\begin{tabular}{|l|l|l|}
\hline $\begin{array}{c}\text { Elements of social } \\
\text { intelligence } \\
\text { structure }\end{array}$ & \multicolumn{1}{|c|}{ Indicators } & \multicolumn{1}{c|}{ Diagnostic methods } \\
\hline $\begin{array}{l}\text { Emotional } \\
\text { intelligence }\end{array}$ & Empathy & $\begin{array}{l}\text { Method of express } \\
\text { diagnosis of empathy } \\
\text { (I.M. Yusupov). }\end{array}$ \\
\hline $\begin{array}{l}\text { Social-perceptual } \\
\text { anticipation }\end{array}$ & $\begin{array}{l}\text { Understanding the } \\
\text { logic of deployment } \\
\text { the situations }\end{array}$ & $\begin{array}{l}\text { Sub-test "History with } \\
\text { Completion"; Social } \\
\text { Intelligence Test } \\
\text { (J.Guilford). }\end{array}$ \\
\cline { 2 - 3 } Social interaction & $\begin{array}{l}\text { Prediction the } \\
\text { results of social } \\
\text { interaction }\end{array}$ & $\begin{array}{l}\text { Subchasses "Accusation"; } \\
\text { Test of the frustrating } \\
\text { reactions (S.Rosenzweig). }\end{array}$ \\
\hline $\begin{array}{l}\text { Adequacy of } \\
\text { statement in } \\
\text { interaction }\end{array}$ & $\begin{array}{l}\text { Author methods evaluation } \\
\text { the level of speech } \\
\text { experience social } \\
\text { adequacy. }\end{array}$ \\
\hline
\end{tabular}

\section{The role of speech experience in the development of social intelligence of the primary school age children}

In order to test the theoretical considerations, we carried out a pilot empirical study aimed at revealing the relationship between the level of development of social intelligence and the speech experience of primary school age children. The sample consisted of children $(\mathrm{n}=116)$, pupils of schools, town Ternopil, average age -9 years. The respondents were diagnosed with indicators of social intelligence and components of speech experience. The respondents were diagnosed according to the complex methodology presented above.

To analyze the results, a correlation analysis of indicators the level of development of social intelligence and speech experience was used. Correlation analysis allowed to state that the level of development of speech of children of the junior school age is interrelated with the development of social intelligence. There were statistically significant positive correlations between the indicators of structural elements the internal structure of speech experience (speech ability, speech 
capabilities, speech competence, speech activity) and the components of the structure of social intelligence, as shown in Table 2.

Table 2

Correlation between the indicators of the speech experience and the social intelligence

\begin{tabular}{|l|c|c|c|}
\hline & $\begin{array}{c}\text { Emotional } \\
\text { intelligence }\end{array}$ & $\begin{array}{c}\text { Social- } \\
\text { perceptual } \\
\text { anticipation }\end{array}$ & $\begin{array}{c}\text { Social } \\
\text { interaction }\end{array}$ \\
\hline Speech ability & $0,401 * *$ & $0,398 * *$ & $\mathbf{0 , 4 0 2} * * *$ \\
\hline Speech competence & $\mathbf{0 , 4 7 8} * * *$ & $0,379 * *$ & $\mathbf{0 , 6 0 5} * * *$ \\
\hline Speech capabilities & $\mathbf{0 , 5 4 1} * * *$ & $\mathbf{0 , 4 9 8} * * *$ & $0,284 *$ \\
\hline Speech activity & $0,363 * *$ & $\mathbf{0 , 5 6 1} * * *$ & $\mathbf{0 , 6 1 8} * * *$ \\
\hline
\end{tabular}

Note: $*-p<0,05 ; * *-p<0,01 ; * * *-p<0,001$.

The analysis of the correlation relations between the levels of organization of the elements the internal structure of speech experience of primary school age children demonstrates the presence of statistically significant interrelationship between almost all determined elements (at the level of significance $p<0,01$ and $p<0,001$ ). This means that there are interconnections and interdependencies between elements: changes to one element cause changes to other elements. The closest connection is observed between the indicators of speech activity and social interaction $(\mathrm{r}=0,618)$; and between speech competence and social interaction $(\mathrm{r}=0,605)$, as well as between speech activity and social-perceptual anticipation $(\mathrm{r}=0,576)$. This allows us to say that really successful social interaction involve with speech activity. But this speech activity does not connect with emotional intelligence $(r=0,363)$. This is very interesting and important conclusion. That means that the primary school age children can feel emotions but can't put it into words. This conclusion is important both for practical and theoretical studies - we have to teach children of primary school age to verbalize their emotions and feelings.

Speech capabilities do not affect the success of social interaction $(r=0,284)$. That is, speech capabilities are always original, unique and unique speech statements. Those who, in the context of communication between children of primary school age, do not always contribute to mutual understanding. In this age period, the preference is given to a 
well-established, standard, understandable statements. However, children with speech capabilities have a much range of vocabulary of words to notification emotions and use them skillfully, which explains the high correlation between speech capabilities and emotional intelligence $(r=0,541)$.

The next task of our study was to identify the mutual relations and the impact of social intelligence and speech experience in general. Is there a high level of social intelligence related with a high level of speech experience? Or, maybe, the level of speech experience does not affect the functioning of social interaction abilities at all?

The logic of empirical research involved the differentiation respondents into groups according to the level of development of social intelligence. Determination of the level of each indicator had made it possible to determine the general level of social intelligence as an overall results indicator. The general level of social intelligence is determined by means of conversion the marks into balls and levels: medium group rate $(\mathrm{M})=17,113$, so high: $20-26$ points; the average: 15-19 points; low: 8-14 points. Accordingly, revealed that 24,14\% of children characterized by a high level of social intelligence, 54,31\% average and $21,55 \%$ - a low level of social intelligence. Such counting was done with the results of diagnostic the level of organization the speech experience. So, high level of speech experience had 26,72\% respondents, average $-61,21 \%$ and low level $-12,07 \%$ of respondents. Figure 1 presents the proportion of the levels, classified by categories "social intelligence" and "speech experience".

These diagram shows that in generally level of speech activity is higher than social intelligence. That is children of primary school age can express their thoughts better than organize and predict social interaction.

Significant correlations between the general level of organization the speech experience and the general level of development the social intelligence have been shown in Table 3.

We can see that almost all performance of social intelligence and speech experience have statistically significant correlations. That demonstrates the close connection between children's speech and social abilities. The qualitative analysis of children's responses give us interesting conclusions. The high level of organization the speech experience does not always determine the success of predicting the most 
adequate scenario of the development of events in the social situation. A group of respondents with an average level of speech experience found a higher correlation with the ability to determine the sequence of events logic $(r=0.624)$, we explain this with some impulsiveness of responses of children with "fast" speech.

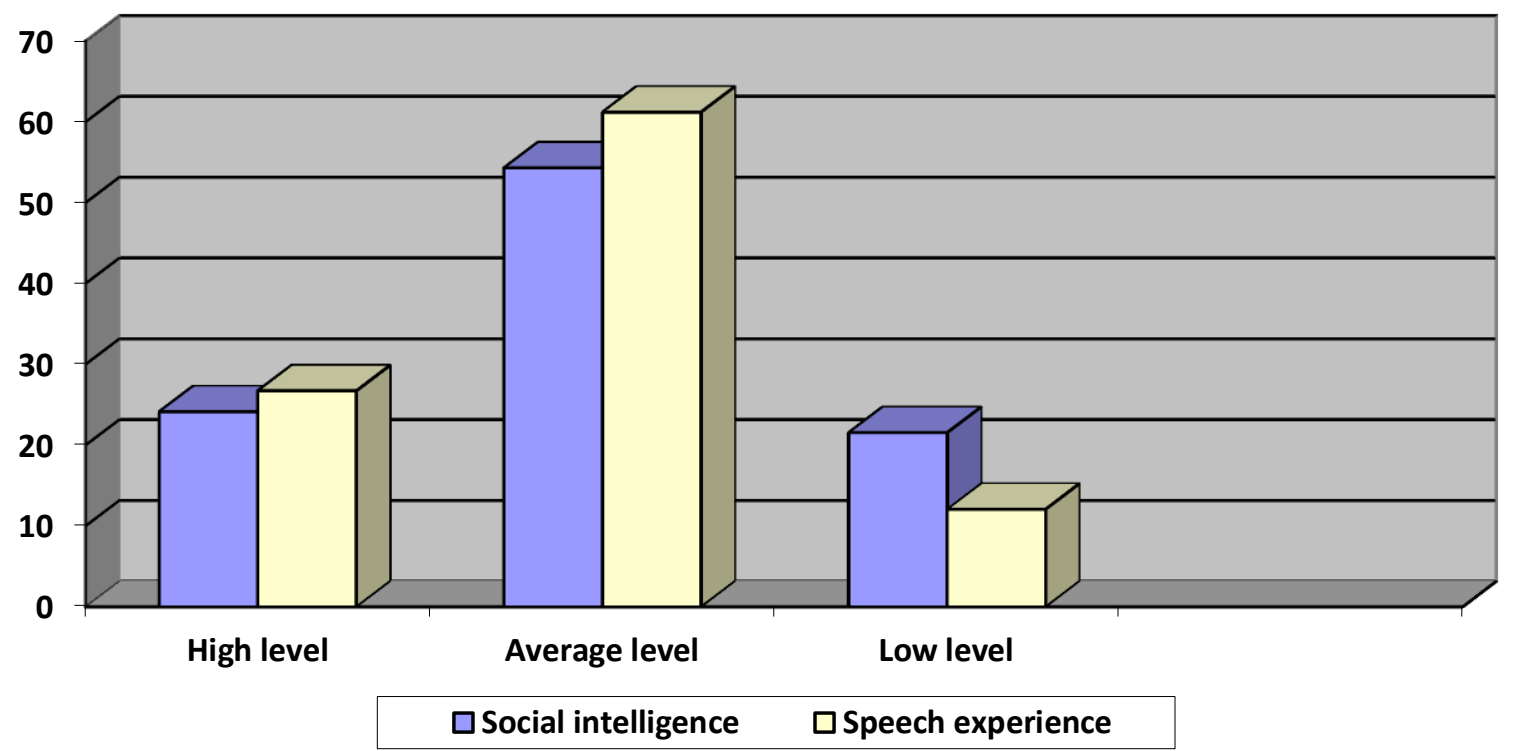

Fig. 1. Proportion of respondents, classified by level of development social intelligence and speech experience

Table 3

Correlation between the indicators of the general level of development the speech experience (SE) and the level of development the social intelligence (SI)

\begin{tabular}{|l|c|c|c|}
\hline & High level SI & $\begin{array}{c}\text { Average level } \\
\text { SI }\end{array}$ & Low level SI \\
\hline High level SE & $0,373 * *$ & $\mathbf{0 , 5 0 1} * * *$ & $0,295 *$ \\
\hline Average level SE & $\mathbf{0 , 6 2 4} * * *$ & $\mathbf{0 , 4 3 4} * * *$ & $\mathbf{0 , 4 6 1} * * *$ \\
\hline Low level SE & $0,391 * *$ & $\mathbf{0 , 5 3 5} * * *$ & $\mathbf{0 , 6 1 8} * * *$ \\
\hline
\end{tabular}

Note: $*-p<0,05 ; * *-p<0,01 ; * * *-p<0,001$.

\section{CONCLUSIONS}

The development of the structural elements of the speech experience internal structure enable implementation of child's speech 
interaction with the world and determines qualitative and quantitative expression characteristics of the internal structure in the external structure. According to the proposed structural model child's speech development is in changing the relationships between the structural elements of internal and external structures of speech experience: its organizing and hierarchy.

Our research answered the discussion in the scientific literature about the influence / independence the personality's verbal system and his social intelligence. The results of the study show that primary school age children have a close connection between all the elements of the internal structure of speech experience and elements of social intelligence. In addition, the general level of development the speech experience is significantly interrelated with the general level of development the social intelligence. This proves the hypothesis that social intelligence is built and functioning on the basis of the system of personality's speech experience.

\section{SUMMARY}

The article provides the results of theoretical and empirical research the relationship between development of social intelligence and speech experience of primary school age children. In the article describes the importance and main directions of studies the concept "social intelligence" in scientific psychological literature. The author's model of speech experience presented. It is shown that functioning of speech experience is provided by internal structure (speech ability, speech competence, speech capabilities, speech activity). The peculiarities of development of social intelligence at the primary school age are revealed, structural components, indicators and diagnostic tools for empirical research of each element of social intelligence are defined.

The analysis of empirical data the level of organization of the speech experience's internal structure is given. The study identified statistically proven correlation between the level of social intelligence and speech experience. This proves that social intelligence in the primary school age development in close interrelationship with speech experience. 


\section{REFERENCES}

1. Айзенк Г.Ю. Понятие и определение интеллекта. Bonpocbl психологии. 1995. № 1. С. 111-131.

2. Батраченко І.Г. Психологія розвитку антиципації людини : монографія. Д. : Вид-во ДНУ ім. О. Гончара, 1996. 204 с.

3. Гриб Е.В. К вопросу о соотношении социального и других видов интеллекта. Историческая и сочиально-образовательная мыслль. Том 9. № 1/1, 2017. С. 58-71.

4. Драган А.О. Розвиток міжособистісних відносин дітей молодшого шкільного віку. Науковий вісник Миколаївського національного університету імені В.О. Сухомлинського. Серія : Педагогічні науки. 2015. № 1. С. 117-121.

5. Журавльова Л.П. Психологія емпатії: монографія. Житомир: Вид-во ЖДУ ім. І Франка, 2007. 327 с.

6. Засєкіна Л.В. Структурно-функціональна організація інтелекту : монографія. Острог : Вид-во Нац. ун-ту «Острозька академія», 2005. 370 с.

7. Івашкевич Е.3. Соціальний інтелект педагога : монографія. К.: Принт-Хауз, 2017. 532 с.

8. Ковалевская А.В. Опыт психологического исследования феномена эмпатии у младших школьников 9-11 лет. Психология. 2005. № 2. C. 31-37.

9. Леонтьев А.А. Основы психолингвистики: научн. пособие. 3-е изд. М. : Смысл; СПб : Лань, 2003. 287 с.

10. Люсин Д.В., Ушаков Д.В., Социальный интеллект: теория, измерение, исследования: монография. М., Изд-во «Институт психологии РАН», 2004. 176 с.

11. Ляховець Л.О. Вікові особливості становлення соціального інтелекту. Вісник Чернігівського національного педагогічного університету. 2015. № 126. С. 102-106.

12. Мельник А.А. Особливості прояву складових соціального інтелекту дітей шкільного віке. Вісник Харківського національного університету ім. В.Н. Каразіна. Серія Психологія. 2011. № 959. Вип. 46. С. 109-113.

13. Орап М.О. Психологія мовленнєвого досвіду особистості: монографія. Тернопіль: «Підручники і посібники», 2014. 480 с. 
14. Cantor N. Personality and social intelligence. N. Cantor, J.F. Kihlstrom. - NJ Prentice-Hall,1987. 200 p.

15. Guilford J.P. The nature of human intelligence. N.Y.: McGrawHill, 1967. 156 p.

Information about the author:

Orap M. O.

Doctor of Psychology,

Professor of the Department of Psychology Volodymyr Hnatiuk Ternopil National Pedagogical University

2, Kryvonosa str., Ternopil, 46027, Ukraine 